\title{
Psychological Constructs of Socio-economic Status of Heads of Farm Families in Delta State Nigeria
}

\author{
B. O. Ovwigho \\ Department of Agricultural Economics and Extension Delta State University, Asaba Campus. Asaba. Delta \\ State, Nigeria
}

\begin{abstract}
This study examined the relationship between socio-economic status and psychological construct of heads of farm families in Delta State. Multi-stage and stratified simple random sampling procedures were used in composing the sample. The sample was made up of 510 heads of farm families drawn from Delta Ibo (174), Urhobo (147), Ijaw (87), Isoko (60), and Itsekiri (42). Questionnaire was used in data collection. Data were analyzed by the use of Sigma scoring method, mean, analysis of variance, multiple regression and factor analysis. The valid psychological constructs were adoption behaviour, leadership abilities, cosmopoliteness, education level, and attitude to innovation. There was a significant relationship between socio-economic status and the valid psychological constructs of the heads' of farm families ( $F=333.29497 ; p<0.05)$. The multiple regression analysis showed that 76.78 percent of socio-economic status was explained by the valid psychological constructs of heads of farm families. The psychological constructs of socio-economic status of heads of farm families in any locality should be understood by the extension agent so as to foster a good working relationship with the farmer.
\end{abstract}

Key Words: Socio-economic Status, Adoption, Leadership, Cosmopolitness, Education, Attitude, Innovation.

\section{Background of the Study.}

\section{Introduction}

According to Chapin (1933) as cited by Akinola and Patel (1987), Rogers (1983). Tubbs (1988), and Onwueme and Ugbor (1994), defined socio-economic status as the position an individual occupies with respect to the amount of cultural possession, effective income, material possession, prestige and social participation. Goode (1974), stated that it was the family and not the individual that was ranked in a class society He noted that the family is the keystone of any stratification system and the social mechanism by which it is maintained.

Socio-economic status scale serves two major importance of measuring changes in socio-economic status, and establishing its implicit relationship to related psychological constructs. The Psychology Glossary (2013) defined a construct as any complex psychological concept. These include a person's motivation, anger, personality, intelligence, love, attachment or fear. Constructs were not concrete materials which could be easily measured. However constructs were useful in interpreting empirical data and building theories. DeVellis (1991) stated that scale development was concerned with measuring phenomena that we believe to exist but that cannot be observed directly. In the social sciences, these phenomena were referred to as constructs (often said to be concepts in the humanities), and measures were considered proxies for these constructs. When we assess the relationships between measures, we infer relationships between the constructs they were intended to measure.

Constructs vary among discipline and organizations. The types of constructs valued in agricultural extension might be different from those valued in sports, theatre arts and education. In agricultural extension communication Rogers (1983), Ogunfiditimi (1981), Gartrell and Gartrell (1985), and Akinoa and Patel (1987), found a positive relationship between socio-economic status and adoption of new technologies. In terms of socio-economic status and leadership Rogers (1983), averred that opinion leaders have higher socio-economic status than their followers. In a study conducted on Brazilian farmers, he found that opinion leaders had larger farms, more change agent contact and high agricultural innovativeness. On socio-economic status and cosmopoliteness, AIao (1976), discovered a positive relationship. Jagne arid Patel (1981), and Alao (1976), defined cosmopoliteness as the degree of participation by an individual in the communication process of an external system

Commenting on the relationship between socio-economic status and education, Onwueme and Ugbor (1994), and Obasi (1987), stated that education serves as a vehicle for upward social mobility by affording talented youths from families in the lower status categories opportunity of climbing high on the socio-economic ladder. Education places individuals in various social positions according to ability and achievement.

Other personal characteristics of farmers worthy of mention are conservatism and fatalism. Raintree (2000) stated that cultural conservatism was seen by anthropologists as a community's way of defending itself against disruptive changes. It is done to preserve the core values of their cultural identity and avoid risks they believe change could bring. Sofranko (1984), stated that fatalism among rural farm families was characterized 
by resignation, passivity, feeling that one lacks the ability to influence the future, and that the outside world is unpredictable.

\section{Statement of the Problem}

The study was precipitated by the variegated psychological challenges that consternate the farmer in a bid to improve his standard of living. This study germane an empirical investigation of the relationship between the higher order behaviours of the low and high socio-economic status heads of farm families. Van der ploeg (1994) as cited by Ghiasy and Mirakzadeh (2012) stated that apart from economic factors farmers decision making was affected by a set of complex behaviours which included imagination, beliefs, knowledge, norms and experiences. Bernard et.al (2011) reported that fatalism was customarily, if not always formally or explicitly, attributed to Ethiopians - particularly to those who were poor. Akinsanmi (2001) noted that in West Africa and many other under-developed regions farmers were considered to occupy the lowest ranks in society. $\mathrm{He}$ mentioned that their skills do not receive the public recognition accorded those of other professions. He also noted that people in white-collar jobs often do have a higher standard of living than the average farmer. The foregoing generalization could be accepted but there is the need to establish the behavioural relationship within classes of farm families.

This paper has, therefore, been designed to investigate the relationship between socio-economic status and psychological constructs of heads of farm families in Delta State The specific objectives were to: (i) validate the psychological constructs related to socio-economic status in the study area; (ii) measure quantitatively the valid psychological constructs; and (iii) ascertain the relationship between socio-economic status and psychological constructs of the heads of farm families.

Hypothesis The null hypothesis tested that; there was no significant relationship between socio-economic status and psychological constructs of heads of farm families.

\section{Materials And Methods}

Sampling Procedure and Sample Size

Heads of farm families in the five major ethnic groups (Urhobo, Delta lbo, ljaw, Itsekini and lsoko) in

Delta Stats, Nigeria were sampled using multistage and stratified simple random sampling procedures.. Ten Local Government Areas were randomly selected from the 25 Local Government Areas in the State on the basis of ethnic and sub- ethnic groups. Forty percent of the towns and villages in a selected Local Government Area were randomly selected. Twelve percent of heads of farm families were randomly selected from the selected Local Government Areas. This gave a sample size of 510 respondents consisting Delta Ibo (174), Urhobo (147), Ijaw (87), Isoko (60), and Itsekiri (42) (see Table 1). Five contact and five non-contact farmers were selected from each ethnic group to validate the psychological constructs related to socio-economic status. This sample was made up of fifty (50) respondents.

\section{Instrument for Data Collection}

Two sets of questionnaires were used in data collection. The first set was administered to the respondents for the purpose of validating the psychological constructs. The second set was administered to measure and establish the relationship between the valid psychological constructs and socio-economic status of the heads of farm families. The second questionnaire consisted of five sections: adoption of recommended technologies, leadership positions, cosmopoliteness, education, and attitude to innovations. A socio-economic status scale constructed for heads of farm families in Delta State by Ovwigho (2000) and validated in 2012 was used to measure the socio-economic status of the heads of farm families. The researcher together with fifteen trained enumerators collected tie data within a period of three months.

\section{Measurement of Variables}

The validation of the psychological constructs was done by the use of a four-point Likert type scale. The scale consisted of Strongly Agree (4); Agree (3); Disagree (2) and Strongly Disagree (1). A cut-off point below and above 2.50 was used to dichotomize the responses into not valid and valid constructs respectively. The valid psychological constructs were scored by the use of Sigma scoring method. The Sigma scoring was used to demonstrate the conversion of qualitative to quantitative responses (Tables 2, 3, 4, $5 \& 6$ ). A four-point rating scale was used to measure attitude to innovation. A total of ten attitude questions made up of four positive questions and six negative questions were constructed. Leadership was measured by the various leadership positions held by the head of farm family. Educational level was measured by the last qualification. Cosmopoliteness was measured by the number of times the individual has travelled outside the village. Adoption was measured by adoption responses to the application of inorganic fertilizers. 


\section{Data Analysis}

Mean scores were used to validate the psychological constructs. Sigma scoring method was used to demonstrate the measurement of psychological constructs. The relationship between socio-economic status and psychological constructs of heads of farm families was analyzed by the use of multiple regression and factor analysis.

\section{Results And Discussion}

Validation of Psychological Constructs

A universe of ten (10) psychological constructs related to socio-economic status were collated from secondary sources. These included fatalism, conservatism, adoption of innovations, feelings of inferiority, leadership abilities, social participation, cosmopoliteness, level of education, risk aversion and attitude to innovations. The respondents' ratings of the extent to which these constructs were contiguous with socioeconomic status was presented in Table 1 ,

Table 1: Valid constructs of socio-economic status of heads of farm families

\begin{tabular}{lllll}
\hline S/N & Construct & Item Total Score & $\begin{array}{l}\text { Mean } \\
\text { Max=4 }\end{array}$ & Remarks \\
1 & Fatalism & 73 & 1.46 & Not valid \\
\hline 2 & Conservatism & 76 & 1.52 & Not valid \\
3 & Adoption behaviour & 159 & 3.18 & Valid \\
4 & Feelings of inferiority & 89 & 1.78 & Not valid \\
5 & Leadership abilities & 150 & 3.00 & Valid \\
6 & Social Participation & 120 & 2.40 & Not valid \\
7 & Cosmopoliteness & 143 & 2.86 & Valid \\
8 & Level of Education & 155 & 3.10 & Valid \\
9 & Risk aversion & 94 & 1.88 & Not valid \\
10 & Attitude to innovation & 146 & 2.92 & Valid
\end{tabular}

Five (5) constructs of socio-economic status were valid. These were: adoption behaviour ( $\mathrm{M}=3.18)$, leadership abilities $(\mathrm{M}=3.00)$, cosmopoliteness $(\mathrm{M}=2.86)$, level of education $(\mathrm{M}=3.10)$ and attitude to innovation $(\mathrm{M}=2.92)$. . Sofranko (1984), stated that the values of rural people include fatalism, familism, low empathy, aversion to risk, traditionalism, immediate gratification and submission to nature.

\section{Scores of Valid Psychological Construct}

The first four valid psychological constructs were scored using Sigma scoring method

\section{Adoption Behaviour}

Adoption behaviour was scored by using adoption of imorganic fertilizer which was disseminated to the farmers by the Delta Agricultural Development Programme (Tables 2 and 3). Based on the responses the scores for the items measure under adoption were awareness of fertilizer (yes $=4$, no $=0$ ), actual application ( yes $=5$, no=2), intention to continue ( yes $=5$, no=2), less than 5 months of fertilizer application $(0), 6-10$ months (2), 11 - 15 months (2), 16-20 months (3), 21 - 25 months (4), 26- 36 months (4), and above 3 years (6). The total score for a respondent in the two Tables were added up to give the score for adoption behaviour of the respondent.

Table 2: Sigma scoring for awareness, actual application and intention to continue the use of fertilizer

\begin{tabular}{lccccc}
\multicolumn{1}{c}{ Item } & $\begin{array}{c}\text { Response } \\
\text { Categories }\end{array}$ & $\mathbf{F}$ & Proportion & $\mathbf{Z}$ & $\begin{array}{c}\text { Standard Score } \\
(\mathbf{Z}+\mathbf{2}) \mathbf{2}\end{array}$ \\
\hline Awareness of fertilizer & Yes & 498 & 0.512 & 0.030 & 4 \\
& No & 12 & 0.012 & 0.257 & 0 \\
Actual application & Yes & 293 & 0.706 & 0.542 & 5 \\
& No & 205 & 0.206 & -0.820 & 2 \\
Intention to continue & & & & & 5 \\
& Yes & 229 & 0.609 & 0.227 & 2 \\
\hline
\end{tabular}

NB: F= Frequency, $\mathrm{P}=$ Proportion (convert to proportion of 100 ), $\mathrm{Z}=$ Sigma score

(Check Table of normal deviates $\mathrm{z}$ ) 
Table 3: Sigma scoring procedure for duration of fertilizer use

\begin{tabular}{lcccccc}
\hline Response categories & F & CF & CFM & CPM & Z & $\begin{array}{l}\text { Standard score } \\
(\mathbf{Z + 2}) \mathbf{2}-\end{array}$ \\
\hline Less than 5 months & 22 & 22 & 11 & 0.038 & -1.774 & 0 \\
6-10 months & 23 & 45 & 33.5 & 0.114 & -1.206 & 2 \\
11- 15 months & 32 & 77 & 61 & 0.208 & -0.815 & 2 \\
16-20 months & 25 & 102 & 89.5 & 0.305 & -0.510 & 3 \\
21 - 25 months & 36 & 138 & 120 & 0.410 & -0.228 & 4 \\
26-36 months & 28 & 166 & 152 & 0.519 & 0.048 & 6 \\
Above 3 years & 127 & 293 & 229.5 & 0.783 & 0.782 & 6 \\
\hline
\end{tabular}

NB: $F=$ Frequency $C F=$ Cumulative Frequency CFM = Cumulative Frequency to Mid-point CPM = Cumulative Proportion to Mid-point, $\mathrm{Z}=$ Sigma Score (Check Table of normal deviates z).

\section{Leadership Abilities}

This was measured by asking the farmers to mention the leadership positions they have held or presently holding and were scored using Sigma scoring method (Table 4). A respondent who has been a village head was scored 7, executive member of a social club (8), contact farmer (7), opinion leader (7), Chief (7), religious leader (7), executive member of a cooperative society (6), and no leadership position (3). The scores were aggregated to make up the leadership score for a respondent

Table 4: Scores for leadership positions

\begin{tabular}{llllccc}
\hline S/N & Leadership Positions & $\mathbf{F}$ & $\mathbf{\%}$ & Proportion & $\mathbf{Z}$ & $\begin{array}{l}\text { Standard } \\
\text { score } \\
(\mathbf{Z + 2}) \mathbf{2} 2\end{array}$ \\
\hline 1 & & & & & & 7 \\
2 & Village Head & 50 & 9.80 & 0.951 & 1.655 & 8 \\
3 & Executive member of a social club & 38 & 7.45 & 0.963 & 1.787 & 7 \\
4 & Contact Farmer & 78 & 15.29 & 0.924 & 1.433 & 7 \\
5 & Opinion leader & 62 & 12.16 & 0.939 & 1.546 & 7 \\
6 & Chief & 72 & 14.12 & 0.929 & 1.463 & 7 \\
7 & Religious leader & 70 & 13.73 & 0.931 & 1.483 & 6 \\
& Executive member of a cooperative society & 121 & 23.73 & 0.881 & 1.180 & \\
8 & No leadership position & 237 & 46.47 & 0.232 & -0.732 & 3 \\
\hline
\end{tabular}

\section{Cosmopolitenes}

$\mathbf{s}$ This was measured by the frequency of times the respondent has left his immediate community within the year. The frequencies were converted to Sigma scores and converted to T-scores (Table 5). The scores obtained were more than 15 times a year (61), 10-15 times a year (55), 6-9 times a year (51), 3-5 times a year (48), 1-2 times a year (45) and rarely travelled (38)

Table 5: Scores for cosmopoliteness.

\begin{tabular}{|c|c|c|c|c|c|c|}
\hline Response categories & $\mathbf{F}$ & $\mathbf{C F}$ & CFM & CPM & $\mathbf{Z}$ & $\begin{array}{l}\text { T-Score } \\
10(Z)+50\end{array}$ \\
\hline More than 15 times/year & 133 & -510 & 443.5 & 0.810 & 1.126 & 61 \\
\hline 10-15 times/ year & 65 & 377 & 344.5 & 0.675 & 0.454 & 55 \\
\hline 6-9 times/year & 71 & 312 & 276.5 & 0.5212 & 0.105 & 51 \\
\hline 3-5 times/year & 44 & 241 & 219 & 0.429 & -0.179 & 48 \\
\hline 1-2 times/year & 87 & 197 & 153.5 & 0.301 & -0.522 & 45 \\
\hline Rarely travel & 110 & 110 & 55 & 0.108 & -1.237 & 38 \\
\hline
\end{tabular}

\section{Education Level}

The education level of the respondents were scored using Sigma scoring method and transformed to Tscores (Table 6). A respondent who holds a postgraduate degree was scored 79, HND/First degree (71), NCE (65), City \& Guilds/OND (62), TC II/Model School (59), WASC/SSCE (56), Below SSCE (52), primary Six (48), Below Primary Six (41), and no formal education (30). Education can also be measured by the number of years the individual spent in formal education. 
Table 6: Scores for education level

\begin{tabular}{|c|c|c|c|c|c|c|c|}
\hline & Response categories & $\mathbf{F}$ & $\mathbf{C F}$ & CFM & CPM & $\mathbf{Z}$ & $\begin{array}{l}\text { T-Score } \\
10(Z) 50\end{array}$ \\
\hline 1 & 1 Postgraduate degree & 4 & 510 & 508 & 0.996 & 2.862 & 79 \\
\hline 2 & HND/First degree & 15 & 506 & 498.5 & 0.977 & 1.995 & 71 \\
\hline 3 & NCE & 27 & 491 & 477.5 & 0.936 & 1.522 & 65 \\
\hline 4 & City \& Guilds/OND & 29 & 464 & 449.5 & 0.881 & 1.180 & 62 \\
\hline 5 & TC II/Model School & 56 & 435 & 407 & 0.798 & 0.834 & 59 \\
\hline 6 & WASC/ SSCE & 42 & 379 & 358 & 0.702 & 0.530 & 56 \\
\hline 7 & Below SSCE & 93 & 337 & 290.8 & 0.570 & 0.176 & 52 \\
\hline 8 & Primary Six & 83 & 244 & 202.5 & 0.397 & -0.261 & 48 \\
\hline 9 & Below Primary Six & 140 & 161 & 91 & 0.178 & -0.923 & 41 \\
\hline 10 & No formal education & 21 & 21 & 10.5 & 0.021 & -2.034 & 30 \\
\hline
\end{tabular}

\section{Scoring Procedure for Attitude to Innovation}

This was measured by a four-point Likert type scale and scored by using nominal values of 4 for strongly agree, agree (3), disagree (2) and strongly disagree (1) for ten attitude to innovation statements. The scores ranged from 10-38

\section{Relationship between Socio-economic Status and Valid Constructs of heads of Farm Families}

The summary of the multiple regression coefficients between socio-economic status (dependent variable) and psychological constructs (independent variables) were:
Multiple R
$=0.87624$
$\mathrm{R}$ square
$=0.76779$
Adjusted R square
$=0.76549$

Standard error $=20.74544$

The variables in the equation and analysis of variance are shown in Tables 7 and 8 respectively.

\begin{tabular}{|c|c|c|c|c|c|}
\hline Variable & $\mathbf{B}$ & SEB & Beta & $\mathbf{T}$ & T sig \\
\hline 1. Adoption & 0.235952 & 0.051887 & 0.154088 & 4.547 & 0.000 \\
\hline 2. Leadership & 0.524386 & 0.160801 & 0.083538 & 3.261 & 0.0012 \\
\hline Cosmopoliteness & 2.136536 & 0.112024 & 0.720874 & 19.072 & 0.000 \\
\hline 4. Education Level & 0.337762 & 0.142651 & 0.075761 & 2.368 & 0.0183 \\
\hline \multirow[t]{2}{*}{ Attitude to Innovation Constant } & -0.46667 & 0.221022 & -0.079444 & -2.11 & 0.0352 \\
\hline & 3.112800 & 5.531578 & & 0.563 & 0.5739 \\
\hline
\end{tabular}

Table 8: Analysis of variance

\begin{tabular}{|c|c|c|c|}
\hline Sources & DF & Sum of squares & Mean sum of square \\
\hline $\begin{array}{l}\text { Regression } \\
\text { Residual } \\
\text { F =333.29497 }\end{array}$ & $\begin{array}{c}5 \\
504\end{array}$ & $\begin{array}{c}717205.95037 \\
216908.04179 \\
\text { Siq } F=0.000\end{array}$ & $\begin{array}{c}143441.19007 \\
430.37310\end{array}$ \\
\hline
\end{tabular}

Table 9: Results of factor analysis of psychological constructs of heads of farm families.

\begin{tabular}{lcc}
\hline \multicolumn{1}{c}{ Factor } & Eigen value & \% of variance \\
\hline Adoption $\mathrm{X}_{1}$ & 4.20029 & 70.0 \\
Leadership X $_{2}$ & 0.63970 & 10.7 \\
${\text { Cosmopohteness } \mathrm{X}_{3}}_{\text {Education level X }}$ & 0.42424 & 7.1 \\
Attitude to innovation X $_{5}$ & 0.31797 & 5.3 \\
SES X $_{6}$ & 0.29859 & 5.0 \\
\hline
\end{tabular}

The valid constructs had a significant relationship with socio-economic status. The $\mathrm{R}^{2}$ value of 0.76779 meant that the constructs could predict socio-economic status of the heads of farm families up to $76.78 \%$. Adoption behaviour, leadership abilities, cosmopolitenes, education level and attitude to innovation could be used to explain socio-economic status. This shows th Based on the variables in the equation the prediction equation could be written as follows:

$\grave{\mathrm{Y}}=3.11+0.24 \mathrm{x}_{1} \div 0.52 \mathrm{x}_{2}+2.14 \mathrm{x}_{3}+0.34 \mathrm{x}_{4}-0.47 \mathrm{x}_{5}-0.49$

The above equation could be used to predict socio-economic status of heads of farm families in Delta state given $\mathrm{X}_{1}, \mathrm{X}_{2}, \mathrm{X}_{3}, \mathrm{X}_{4}$, and $\mathrm{X}_{5}$.

The analysis of variance further proved a significant relationship between socio-economic status and personal characteristics of the heads of farm families $(F=333.29 ; \mathrm{p}<0.05)$. The results corroborate the findings of Alao (1976), Rogers (1983), Ekong (2003), Ogunfiditimi (1981), and Akinola and Patel (1987), that there 
was a positive relationship between socio-economic status and personal characteristics of farmers. These characteristics include adoption behaviour, leadership abilities, education, cosmopoliteness and attitude to innovation.

\section{Factor Analysis}

The principal component method of factor analysis was used to determine the factor, which accounted for most of the variance in the data (Table 10). Adoption has the highest eigen value followed by leadership, comopoliteness, education level and attitude to innovation.

\section{Conclusion And Recommendation}

The study established that adoption behaviour, leadership abilities, cosmopolitenes, education level and attitude to innovation were valid constructs of socio-economic status. These measures were measured quantitatively thereby demystifying the popularly held notion that psychological constructs cannot be operationalised and measured. Socio-economic status has a significant and positive relationship with adoption, leadership, cosmopoliteness, education and attitude to innovation. The socio-economic status of heads of farm families in Delta state, Nigeria could be deduced once the adoption, leadership, cosmopoliteness, education level and attitude to innovation scores were known. A fore knowledge of the psychological constructs of heads of farm families is important in determining socio-economic status which is a necessary criterion in relating with the farmer. The psychological constructs of socio-economic status of heads of farm families in any locality should be understood by the extension agent so as to foster a good working relationship with the farmer.

\section{References}

[1] Akinola, C. A. and Patel, A. U. (1987). ' Construction and standardization of a scale to measure socio-economic status of heads of rural house holds ( Gandu) in the Funtua Zone of Kaduna State', Journal of Rural Development, 10: 86-94.

[2] Akinsanmi, O. (2001). Senior secondary agricultural science. London: Longman Group Ltd.

[3] Alao, J. A. (1976), 'The diffusion of fish ponds in western state of Nigeria.' In: Crouch B. R.and S. Chamala (eds). Extension Education and Rural Development, Vol. 1: Chichester: John Wiley and Sons. pp. 209-223.

[4] Bernard, T., Dercon, S., and Taffese, A. S. (2011). Beyond fatalism; an empirical exploration of self-efficacy and aspirations failure in Ethiopia. International Food Policy Research Institute, (IFPRI), Discussion Paper 01101

[5] Devellis RF. Scale development: theory and applications. Vol. 26. Sage Publications; Newbury Park, CA: 1991. (Applied Social Research Methods Series

[6] Ekong, E. E. (2003). An introduction to rural sociology. Uyo: Dove Educational Publishers.

[7] Gartrell, D.C. and Gartrell, J.W. (1985).' Social status and agricultural innovation: a meta-analysis', Rural Sociology, and 50 (1): 38-50.

[8] Ghiasy, F. G. and Mirakzadeh, A. (2012). Analyzing of agricultural wheat farmers behavior related to agricultural advisory services. World Applied Sciences Journal, 16(9):1321-1328

[9] Goldthorpe. J.E. (197'4). An introduction to sociology. London: Cambridge University Press. pp. 19 -21

[10] Goode, W.J. (1974). The family. New Jersey: Prentice Hall Inc.

[11] Horton, P.B. and Chester, L.H. (1984). Sociology. New York: McGraw Hill Book Company. p.345

[12] Jagne, J.N. and Patel, AU. (1981). 'Adoption of the individual and package of improved practices by package and non-package groundnut farmers in the Gambia', The Nigerian Journal of Agricultural Extension, 1 (1): 24-31.

[13] Obasi, E. (1987). Understanding education and society in Nigeria. Owerri: KayBeecee Publications Ltd.

[14] Ogunfiditimi, TO. (1981). Adoption of improved practices: a choice under uncertainty. Indian Journal of Extension Education, 18 (182): 30- 35 .

[15] Onwueme, M.S. and Ugbor, 0. (1994). Edu ation and society: the sociology of education. BeninCity: Nigerian Research Association, University of Benin.

[16] Ovwigho, 8. 0 (2000). Construction and standardization of a socio-economic status scale for farm families in Delta State, Nigeria. PhD Dissertation, University of Ibadan, Nigeria.

[17] Psychology Glossary (2013). Construct. Retrieved from alleydog.com/glossary/definition.php on $14^{\text {th }}$ August 2013

[18] Raintree, J. (2000). Catalyzing innovation in culturally conservative communities. LEISA Newsletter, pp.19-20

[19] Rogers, EM. (1983). Diffusion of innovations. New York : The Free Press.

[20] Sofranko, A.J. (1984). Introducing technological change: the social setting. In: Swanson, B.E. (ed). Agricultural extension. a reference manual. Rome: FAO.

[21] Tubbs, S.L. (1988). A system approach to small group interaction. New York: Random House. 